\title{
Advogado pardo no Tribunal
}

E mais um dia afronto a hostilidade

da elite branca e vil que me detesta.

Aqui no Tribunal a iniquidade

aflige a minha pele e a minha testa...

Por mais que eu diga, afirme, exija ou brade,

Sou vítima do olhar que me molesta...

E, nessa dor, eu sinto a impunidade

De um racismo que encontra sua fresta...

São sorrisos de pura tirania!

São sopros torpes de ódio e de desdém!

São tiros de um rancor que me asfixia!

Mas sigo protestando com meu rosto, feliz de meu nariz que se mantém erguido contra o nojo predisposto! 